\title{
Perancangan Dan Pembuatan Aplikasi Media Pembelajaran Berbasis Android Pada Mata Pelajaran Produk Kreatif dan Kewirausahaan
}

\author{
Nurhayati $^{1}$, Yuliawati Yunus ${ }^{2}$, Astri Indah Juwita ${ }^{3}$ \\ 1,2,3 Universitas Putra Indonesia YPTK Padang \\ Email : nurhyti2198@gmail.com yuliawati_yunus@upiyptk.ac.id astriindahjuwita@gmail.com
}

\begin{abstract}
Abstrak
Penelitian ini bertujuan untuk mengetahui Validitas, Praktikalitas dan Efektivitas Perancangan dan Pembuatan Aplikasi Media Pembelajaran Berbasis Android Pada Mata Pelajaran Produk Kreatif dan Kewirausahaan Kelas XII TKJ 2 di SMK Negeri 8 Padang Semester Ganjil Tahun Ajaran 2020/2021. Penelitian ini menggunakan metode pengembangan penelitian (research \& Development). Subjek penelitian berjumlah 35 orang. Model penelitian yang digunakan adalah model penelitian pengembangan (ADDIE model), dengan desain langkah-langkah pengembangannya adalah sebagai berikut. (1)Analyze, (2) Design, (3) Development, (4) Implementation dan (5) Evaluate. Hasil uji validitas oleh para ahli secara keseluruhan penilaian uji validator terhadap Aplikasi Media Pembelajaran Berbasis Android Pada mata pelajaran Produk Kreatif dan Kewirausahaan Kelas XII TKJ 2 SMKN 8 Padang sebesar Semester Ganjil 82,20\%, sehingga tingkat validitas dapat di interpretasikan Valid digunakan. Hasil penilaian uji praktikalitas secara keseluruhan penilaian praktikalitas terhadap Aplikasi Media Pembelajaran Berbasis Android pada mata pelajaran Produk Kreatif dan Kewirausahaan Kelas XII TKJ 2 SMKN 8 Padang Semester Ganjil sebesar 90,79\%, Sehingga tingkat praktikalitasnya dapat di interpretasikan Sangat Praktis digunakan. Hasil penilaian uji efektivitas secara keseluruhan penilaian efektivitas terhadap Aplikasi Media Pembelajaran Berbasis Android pada mata pelajaran Produk Kreatif dan Kewirausahaan Kelas XII TKJ 2 SMKN 8 Padang Semester Ganjil sebesar 84,91\%, Sehingga tingkat efektivitasnya dapat di interpretasikan Efektif digunakan. Kesimpulannya, berdasarkan penilaian beserta masukan ahli serta hasil dari uji coba lapangan Aplikasi Media Pembelajaran Berbasis Android sebagai media pembelajaran sudah teruji kelayakan, keunggulan, dan dapat digunakan pada proses pembelajaran pada mata pelajaran Produk Kreatif dan Kewirausahaan kelas XII TKJ 2 SMKN 8 Padang.
\end{abstract}

Kata Kunci : Android, Media Pembelajaran, Produk Kreatif dan Kewirausahaan.

\begin{abstract}
This study aims to determine the validity, practicality and effectiveness of designing and making Android-based learning media applications in the subject of Creative Products and Entrepreneurship for Class XII TKJ 2 at SMK Negeri 8 Padang Odd Semester, Academic Year 2020/2021. This study uses a research development method (research \& Development). The research subjects were 35 people. The research model used is the development research model (ADDIE model), with the design of the development steps as follows. (1) Analyze, (2) Design, (3) Development, (4) Implementation and (5) Evaluate. The results of the validity test by the experts as a whole validator test assessment of Android-Based Learning Media Applications in the subject of Creative Products and Entrepreneurship Class XII TKJ 2 SMKN 8 Padang amounting to Odd Semester 82.20\%, so that the level of validity can be interpreted as valid to use. The results of the overall practicality test assessment of the practicality of Android-Based Learning Media Applications in the subject of Creative Products and Entrepreneurship Class XII TKJ 2 SMKN 8 Padang Odd Semester is $90.79 \%$, so that the level of practicality can be interpreted as Very Practical to use. The results of the overall effectiveness test assessment of the effectiveness of the Android-Based Learning Media Application in the subject of Creative Products and Entrepreneurship Class XII TKJ 2 SMKN 8 Padang Odd Semester is $84.91 \%$, so that the level of effectiveness can be interpreted Effectively used. In conclusion, based on the assessment and expert input and the results of the field trial of the Android-Based Learning Media Application as a learning medium, it has been tested for feasibility, excellence, and can be used in the learning process in Creative Products and Entrepreneurship subjects in class XII TKJ 2 SMKN 8 Padang.
\end{abstract}

Keyword : Android, Learning Media, Creative Products and Entrepreneurship. 


\section{PENDAHULUAN}

Sumber belajar yang paling sering digunakan dalam proses pembelajaran Produk Kreatif dan Kewirausahaan adalah buku dan Lembar Kerja Siswa (LKS). Sementara itu, ketersediaan sumber belajar di sekolah tersebut kurang, dikarenakan sumber belajar tersebut terbatas dan hanya tersedia di perpustakaan. Dimana sumber belajar ini memiliki peran penting dalam mempercepat proses belajar siswa untuk memahami materi dan membantu guru untuk menggunakan waktu secara lebih baik.

Berdasarkan wawancara dan observasi yang dilakukan penulis pada hari Kamis tanggal 12 November 2020 dengan guru mata pelajaran Produk Kreatif dan Kewirausahaan di SMKN 8 Padang adalah di karenakan pandemi Covid-19 maka proses pembelajaran di lakukan secara Daring/Online keterbatasan sumber belajar yang ada di sekolah, seperti kurang lengkapnya buku penunjang pembelajaran di sekolah yang nantinya akan mampu meningkatkan hasil belajar siswa dan tidak semua siswa dapat memiliki buku panduan sebagai sumber belajar, karena keterbatasan buku yang ada di sekolah. Pemanfaatan media pembelajaran berbasis teknologi lain seperti $C D$ interaktif yang belum digunakan, dan juga penggunaan media pembelajaran berbasis Android belum ada digunakan. Diperlukan media pembelajaran yang bersifat mandiri yang dapat membuat pembelajaran Daring lebih menarik dengan menggunakan media pembelajaran berbasis Android.

Bersumber pada permasalahan diatas, sehingga penulis merancang suatu media pembelajaran berbasis smartphone Android yang bertajuk Perancangan dan Pembuatan Aplikasi Media Pembelajaran Berbasis Android Pada Mata Pelajaran Produk Kreatif dan Kewirausahaan Kelas XII TKJ 2 di SMKN 8 Padang Semester Ganjil Tahun Ajaran 2020/2021.

\section{METODOLOGI}

Penelitian ini menggunakan penelitian dan pengembangan atau biasa disebut dengan R\&D (research and Development), yaitu metode penelitian yang digunakan untuk menghasilkan produk baru, dan menguji keefektifan produk tersebut (Sugiyono, 2016:311).

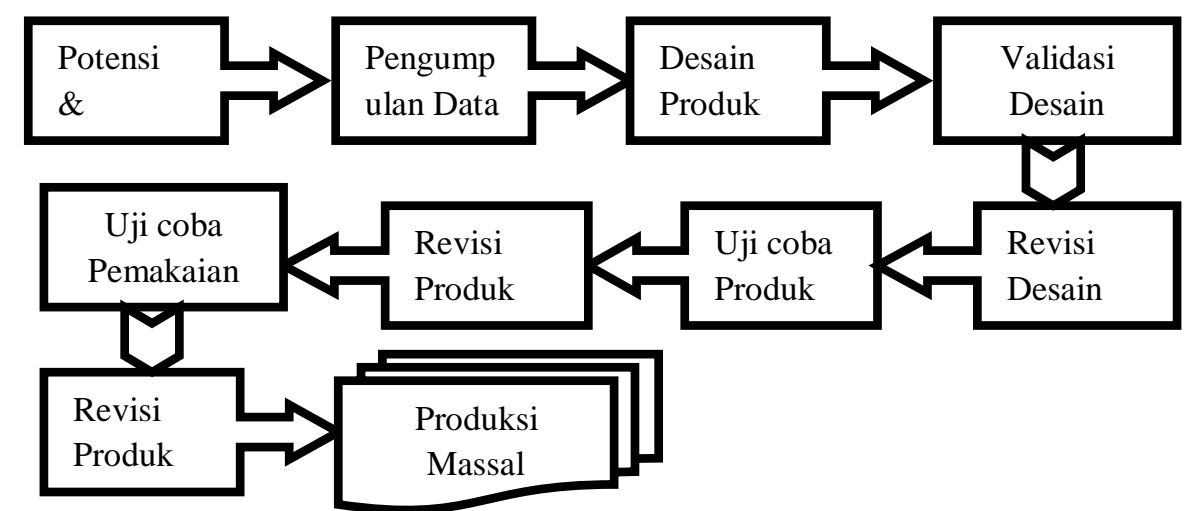

Gambar 1. Langkah-langkah penggunaan Metode Research and Development $(R \& D)$

Saat ini model pengembangan yang dapat digunakan dalam penelitian dan pengembangan Research and development cukup beragam, salah satu model pengembangan yang dapat digunakan dalam penelitian pengembangan adalah model ADDIE (Analyze, Design, Development, Implementation, Evaluation). Model ADDIE merupakan salah satu model desain pembelajaran sistematik. 


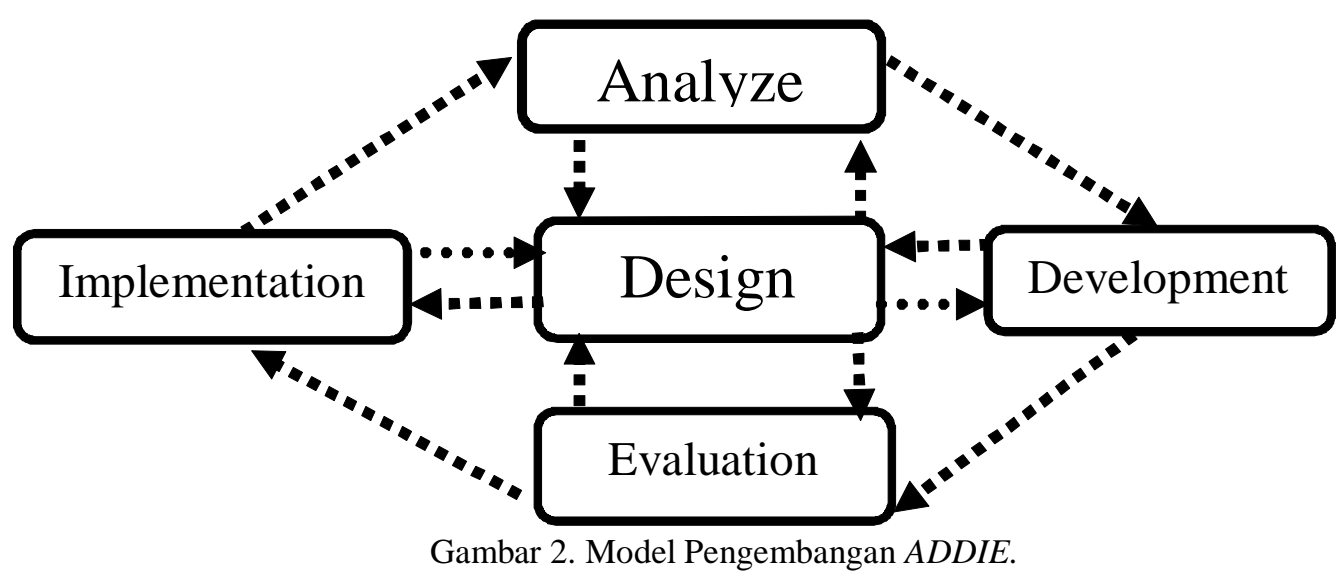

Subjek dalam penelitian ini diambil dari siswa kelas XII TKJ 2 mata pelajaran Produk Kreatif dan Kewirausahaan Semua Jurusan TKJ di SMK Negeri 8 Padang tahun ajaran 2020/2021 berjumlah 35 siswa. Skema desain pembelajaran model ADDIE membentuk siklus yang terdiri dari 5 tahapan yang terdiri dari: analisis (Analysis), desain (Design), pengembangan (Development), implementasi (Implementation) serta evaluasi (Evaluation).

1. Analisis (Analyze)

Langkah awal dalam membuat produk media pembelajaran berbasis android dengan menggunakan model ADDIE adalah dengan menganalisis kondisi yang dibutuhkan dan spesifikasi produk

2. Desain (Design)

Pada tahap ini peneliti mulai merancang produk yang akan di buat. Media pembelajaran berbasis Android dirancang sesuai dengan analisis pada tahap sebelumnya. Spesifikasi produk yang akan dibuat dalam bentuk media pembelajaran menggunakan Microsoft Office Powerpoint berbasis Android.

3. Pengembangan (Development)

Pada tahap ini dilakukan uji validitas yang sudah direvisi berdasarkan masukan yang telah diberikan validator.

4. Implementasi (Implementation)

Setelah uji validalitas dilakukan, uji praktikalitas dilakukan oleh siswa

5. Evaluasi (Evaluations)

Tahap terakhir adalah melakukan evaluasi (Evaluation), dari tahap ini dilakukan dengan diperoleh penilaian dari tes hasil belajar siswa yang dikumpulkan. Tes tersebut dianalisis, dan selanjutnya dapat mengetahui tingkat kelayakan produk media pembelajaran berbasis Android tersebut.

\section{Instrumen Penelitian}

\section{Instrumen Kevalidan}

Instrumen kevalidan digunakan untuk mengetahui apakah media pembelajaran berbasis Android yang telah dirancang valid atau tidak. Dengan kata lain, seluruh instrument yang telah dirancang akan divalidasi terlebih dahulu untuk mengetahui tingkat kevalidan instrument tersebut. Lembar validasi pada penelitian ini adalah validasi yang dilakukan validator. penyebaran dan hasil pengisian angket dilakukan dengan Google Forms.

Tabel 1. Kisi Kisi Angket Validator

\begin{tabular}{|c|l|l|c|}
\hline No & \multicolumn{1}{|c|}{ Indikator } & \multicolumn{1}{|c|}{ Item } & Jumlah \\
\hline 1 & Kelayakan Isi. & $1,2,3,4,5$ & 5 \\
\hline 2 & Komponen Kebahasaan & $6,7,8,9$ & 4 \\
\hline
\end{tabular}




\begin{tabular}{|c|l|l|c|}
\hline 3 & Komponen Penyajian & $10,11,12,13,14,15,16$ & 7 \\
\hline 4 & KomponenKegrafikan. & $17,18,19,20$ & 4 \\
\hline \multicolumn{2}{|c|}{ Total Item } & $\mathbf{2 0}$ \\
\hline
\end{tabular}

Sumber : Riza dan Handayani (2014:124)

Untuk mengubah data kualitatif ke bentuk kuantitatif, maka tes selain di beri alternatif jawaban masing-masing mempunyai bobot dan skor dari setiap jawaban dari pernyataan dapat dilihat pada tabel berikut :

Tabel 2. Penilaian Jawaban

\begin{tabular}{|l|c|c|}
\hline \multicolumn{1}{|c|}{ Pilihan } & Keterangan & Bobot \\
\hline Sangat Setuju & SS & 5 \\
\hline Setuju & S & 4 \\
\hline Kurang Setuju & KS & 3 \\
\hline Tidak Setuju & TS & 2 \\
\hline Sangat Tidak Setuju & STS & 1 \\
\hline
\end{tabular}

Sumber : Sugiyono (2014: 94)

2. Intrumen Kepraktisan

Setelah instrument dinyatakan valid oleh validator, selanjutnya beberapa instrument tersebut digunakan untuk uji kepraktisan.

Tabel 3. Kisi-Kisi Angket Praktikalitas

\begin{tabular}{|c|l|l|c|}
\hline No & \multicolumn{1}{|c|}{ Indikator } & \multicolumn{1}{c|}{ Item } & Jumlah \\
\hline 1 & Keadaan Penggunaan. & $1,2,3,4,5,6,7,8$ & 8 \\
\hline 2 & EfektivitasWaktu Pembelajaran. & $9,10,11,12,13$ & 5 \\
\hline 3 & Manfaat & $14,15,16,17,18$ & 5 \\
\hline \multicolumn{2}{|c|}{ Total Item } & $\mathbf{1 8}$ \\
\hline
\end{tabular}

Sumber : Riza \& Handayani (2014: 125)

Instrumen yang digunakan disusun menurut pola skala dalam bentuk kontiniu yang terdiri dari lima kategori dan pernyataan angket bersifat positif.

Tabel 4. Penilaian Jawaban

\begin{tabular}{lcc}
\multicolumn{1}{c}{ Pilihan } & Keterangan & Bobot \\
\hline Sangat Setuju & SS & 5 \\
\hline Setuju & S & 4 \\
\hline Kurang Setuju & KS & 3 \\
\hline Tidak Setuju & TS & 2 \\
\hline Sangat Tidak Setuju & STS & 1 \\
\hline \multicolumn{2}{c}{ Sumber : Sugiyono $(2014: 94)$}
\end{tabular}

3. Instrumen Keefektifan

Cara pengujian keefektifan media pembelajaran berbasis Android digunakan soal tes belajar.Untuk mengetahui kemampuan belajar siswa, siswa menjawab soal tes belajar.Soal tes belajar diberikan setelah siswa mengikuti proses pembelajaran dengan media pembelajaran berbasis Android. 
Teknik Analisa Data

1. Analisis Uji Validitas media pembelajaran berbasis Android

a) Memberikan skor jawaban dengan kriteria berdasarkan skala Likert yang dimodifikasi oleh Sugiyono (2014: 93) yaitu :

Tabel 6. Penilaian Jawaban validitas

\begin{tabular}{lcc}
\multicolumn{1}{c}{ Pilihan } & Keterangan & Bobot \\
\hline Sangat Setuju & SS & 5 \\
\hline Setuju & S & 4 \\
\hline Kurang Setuju & KS & 3 \\
\hline Tidak Setuju & TS & 2 \\
\hline Sangat Tidak Setuju & STS & 1 \\
\hline \multicolumn{2}{c}{ Sumber : Sugiyono $(2014: 135)$}
\end{tabular}

b) Menentukan skor tertinggi

Skor tertinggi $=$ jumlah validator $\mathrm{x}$ jumlah item pertanyaan $\mathrm{x}$ skor maksimum.

c) Menentukan jumlah skor dari masing-masing validator dengan menjumlahkan semua skor yang di peroleh dari masing-masing indikator.

d) Menentukan skor yang diperoleh dengan menjumlahkan skor dari masing-masing validator.

e) Penentuan nilai validitas dimodifikasi dari Purwanto (2010:102) sebagai berikut: $N P=\frac{R}{S M} \times 100$.

Keterangan:

$\mathrm{NP}=$ Nilai persen yang dicari atau yang diharapkan

$\mathrm{R}=$ Skor mentah yang diperoleh siswa

$\mathrm{SM}=$ Skor Maksimum ideal dari tes yang bersangkutan

$100=$ Bilangan Tetap

f) Memberikan penilaian validitas dengan kriteria yang dimodifikasi dari Purwanto (2010 : 82) berikut ini :

Tabel 7. Klasifikasi Aspek Penilaian Validitas

\begin{tabular}{ccc}
\hline No & Nilai & Aspek yang Dinilai \\
\hline 1 & $90 \%-100 \%$ & Sangat Valid \\
\hline 2 & $80 \%-89 \%$ & Valid \\
\hline 3 & $65 \%-79 \%$ & Cukup Valid \\
\hline 4 & $55 \%-64 \%$ & Kurang Valid \\
\hline 5 & $\leq 54 \%$ & Tidak Valid \\
\hline & Sumber : Purwanto $(2011: 82)$
\end{tabular}

g) Kemudian menentukan nilai distribusi frekuensi validitas yang dimodifikasi dari Prof. Dr. H. Agus I. Irianto berikut ini:

$\mathrm{R}=$ data tertinggi - data terendah

$\mathrm{K}=1+3.3 \log \mathrm{n}$

$\mathrm{P}=\frac{\mathrm{K}}{\mathrm{K}}$

Keterangan :

$\mathrm{P}=$ Panjang kelas interval

$\mathrm{R}=$ Hitung jarak atau rentangan

$\mathrm{K}=$ Jumlah kelas 
2. Analisis Uji Praktikalitas media pembelajaran berbasis Android

Data uji praktikalitas penggunaan media pembelajaran berbasis Android dianalisis dengan menggunakan rumus yang dimodifikasi dari Purwanto (2010: 102) berikut ini:

$$
\begin{aligned}
& \mathrm{NP}=\frac{\mathrm{R}}{\mathrm{SM}} \times 100 . \\
& \text { Keterangan : } \\
& \mathrm{NP} \quad=\text { Nilai persen yang dicari atau yang diharapkan } \\
& \mathrm{R} \quad=\text { Skor mentah yang diperoleh siswa } \\
& \mathrm{SM} \quad=\text { Skor Maksimum ideal dari tes yang bersangkutan } \\
& 100 \quad=\text { Bilangan Tetap }
\end{aligned}
$$

Setelah presentase diperoleh, dilakukan pengelompokkan sesuai kriteria yang dimodifikasi dari Purwanto (2010 : 103) berikut ini :

Tabel 8. Penilaian Praktikalitas

\begin{tabular}{lcc}
\hline No & Nilai & Aspek Yang Dinilai \\
\hline 1 & $86 \%-100 \%$ & Sangat Praktis \\
\hline 2 & $76 \%-85 \%$ & Praktis \\
\hline 3 & $60 \%-75 \%$ & Cukup Praktis \\
\hline 4 & $55 \%-59 \%$ & Kurang Praktis \\
\hline 5 & $\leq 54 \%$ & Tidak Praktis \\
\hline \multicolumn{2}{c}{ Sumber : Purwanto $(2011: 103)$}
\end{tabular}

Kemudian menentukan nilai distribusi frekuensi praktikalitas yang dimodifikasi dari Prof.

Dr. H. Agus I. Irianto berikut ini:

$\mathrm{R}=$ data tertinggi - data terendah

$\mathrm{K}=1+3.3 \log \mathrm{n}$

$\mathrm{P}=\frac{\mathrm{R}}{\mathrm{K}}$

Keterangan :

$\mathrm{P} \quad=$ Panjang kelas interval

$\mathrm{R} \quad=$ Hitung jarak atau rentangan

$\mathrm{K} \quad=$ Jumlah kelas

3. Analisis Efektifitas Media pembelajaran berbasis Android

Data angket efektifitas Media pembelajaran berbasis Android diperoleh dengan cara menghitung skor siswa yang menjawab masing-masing item sebagaimana terdapat pada angket. Data tersebut dianalisis dengan teknik persentase yang dinyatakan oleh Purwanto (2010 : 102) sebagai berikut :

$\mathrm{NP}=\frac{\mathrm{R}}{\mathrm{SM}} \times 100$.

Keterangan :

$\mathrm{NP}=$ Nilai persen yang dicari atau yang diharapkan

$\mathrm{R}=$ = Skor mentah yang diperoleh siswa

SM = Skor Maksimum ideal dari tes yang bersangkutan

$100=$ Bilangan Tetap

Hasil yang diperoleh di interprestasikan dengan menggunakan kriteria sebagai berikut :

Tabel 9. Penilaian Efektivitas

\begin{tabular}{lcc}
\hline No & Nilai & Aspek Yang Dinilai \\
\hline 1 & $86 \%-100 \%$ & Sangat Baik \\
\hline 2 & $76 \%-85 \%$ & Baik \\
\hline 3 & $60 \%-75 \%$ & Cukup \\
\hline 4 & $55 \%-59 \%$ & Kurang \\
\hline 5 & $\leq 54 \%$ & Kurang Baik \\
\hline \multicolumn{2}{c}{ Sumber : Purwanto $(2011: 103)$}
\end{tabular}


Kemudian menentukan nilai distribusi frekuensi efektifitas yang dimodifikasi dari Prof. Dr. H. Agus I. Irianto berikut ini:

$\mathrm{R}=$ data tertinggi - data terendah

$\mathrm{K}=1+3.3 \log \mathrm{n}$

Keterangan :

$$
\mathrm{P}=\frac{\mathrm{R}}{\mathrm{K}}
$$

$\mathrm{P} \quad=$ Panjang kelas interval

$\mathrm{R} \quad=$ Hitung jarak atau rentangan

$\mathrm{K} \quad=$ Jumlah kelas

\subsection{Rancangan Interface}

Desain user interface merupakan desain tampilan sistem yang akan dibuat, mulai dari desain input dan desain ouput.

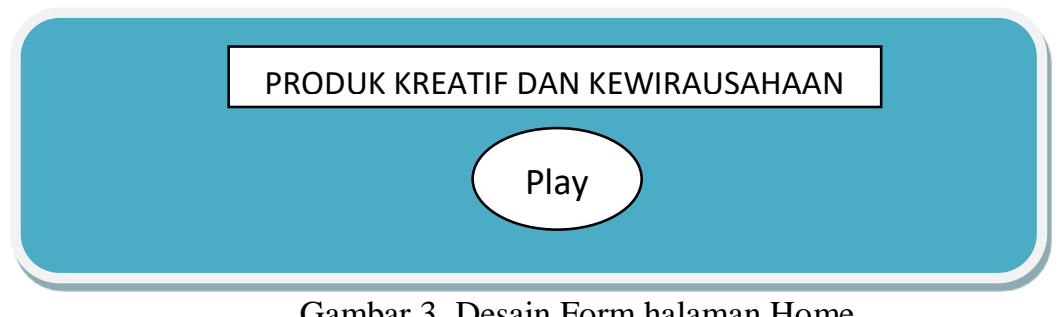

Gambar 3. Desain Form halaman Home

\section{HASIL DAN PEMBAHASAN}

\section{Hasil Rancangan}

a. Halaman Menu awal (Intro)

Intro yang menggambarkan tampilan awal saat memulai aplikasi media pembelajaran berbasis android. Pada halaman ini dilengkapi dengan tombol Play untuk masuk ke halaman Home.

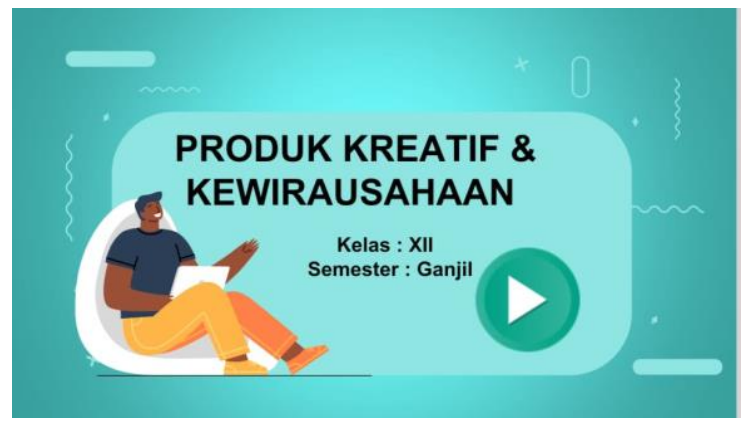

Gambar 4. Halaman Intro

b. Halaman Home

Home yang mengambarkan tampilan awal saat memasuki media pembelajaran berbasis android. Pada Home ini di lengkapi dengan tombol yang akan dapat memilih ke halaman yang ingin di tuju pada gambar dibawah ini : 


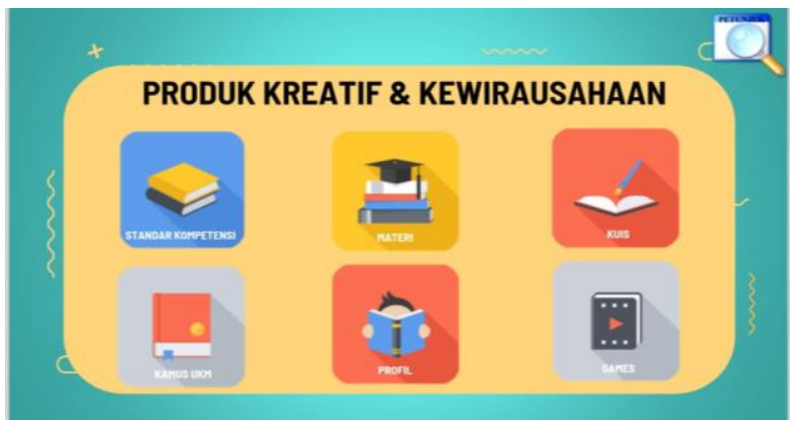

Gambar 5. Halaman Home

Pada halaman Home ini memiliki 7 Sub Menu yaitu:

1. Standar Kompetensi

2. Materi

3. Kuis

4. Kamus UKM

5. Profil

6. Games

7. Petunjuk

c. Halaman standar kompetensi

Dalam halaman ini berisi tentang penjelasan singkat mengenai standar kompetensi dan indikator pembelajaran. Selain itu terdapat tombol next untuk ke halaman selanjutnya dan tombol Home untuk kembali ke halaman Home pada gambar dibawah ini :

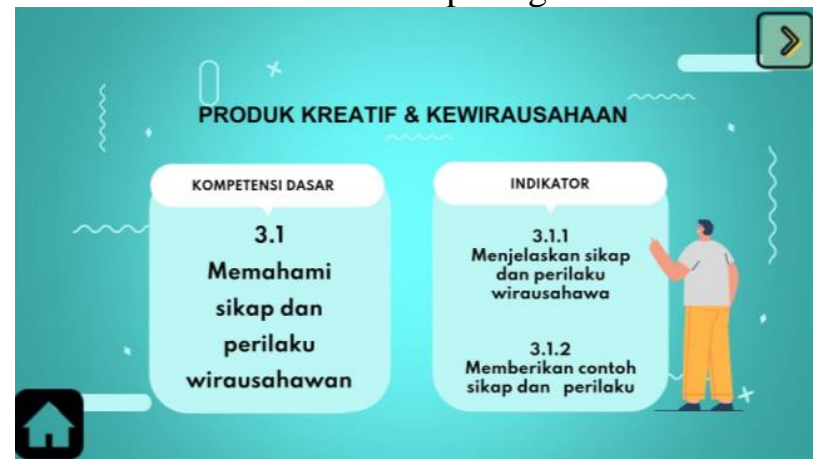

d. Halaman Menu materi

Gambar 6. Halaman Standar Kompetensi

Tampilan Menu Materi ini berfungsi untuk melihat dan membaca materi-materi Produk Kratif dan Kewirausahaan. Tombol Home untuk kembali ke Menu utama.

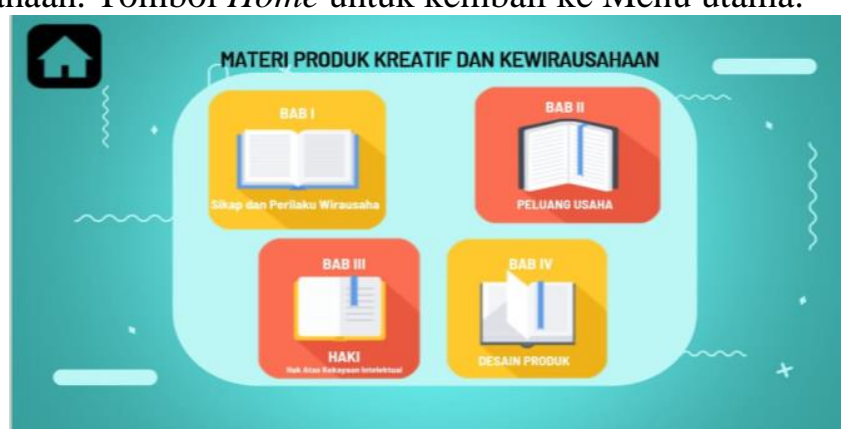

Gambar 7. Halaman Menu Materi

Setelah klik tombol Menu materi diatas maka akan muncul halaman berisikan video pembelajaran mengenai materi Produk Kreatif dan Kewirausahaan. 


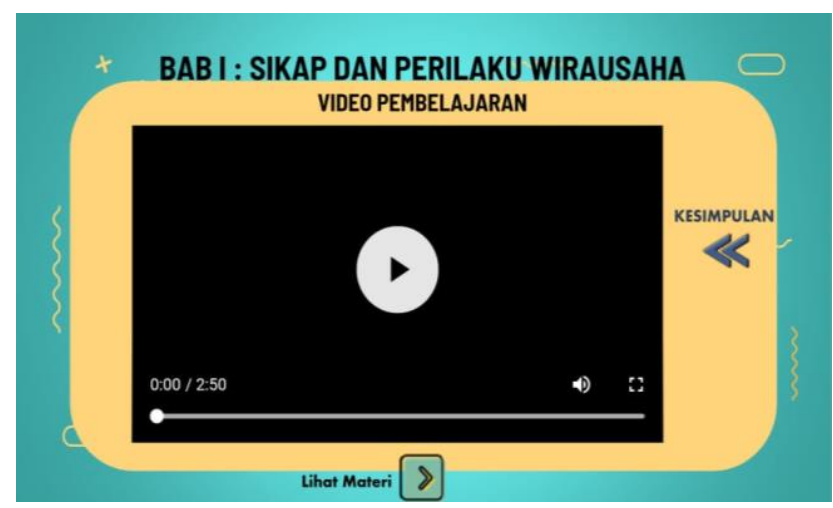

Gambar 8. Halaman Video Pembelajaran

Kemudian tombol Kesimpulan berisikan rangkuman dari video pembelajaran tersebut seperti pada gambar dibawah ini :

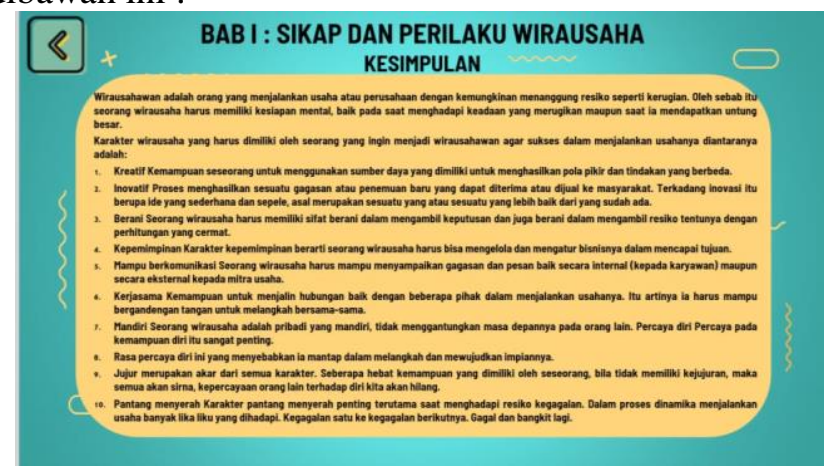

Gambar 9. Halaman Materi

Setelah membuka halaman materi maka akan muncul per bab materi dalam bentuk buku.

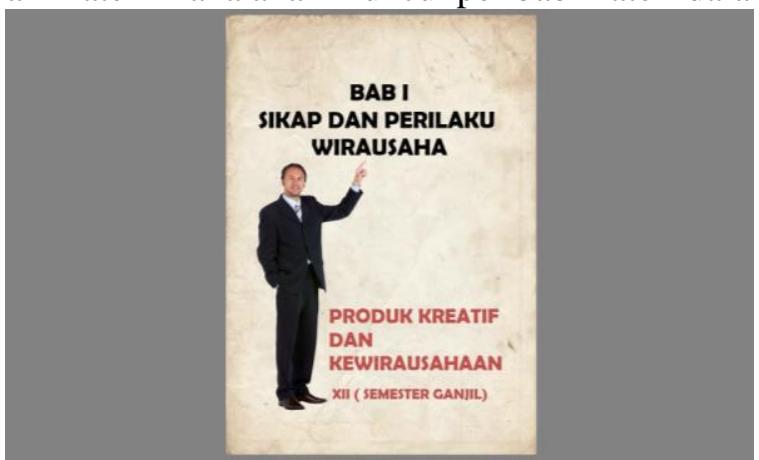

Gambar 10. Halaman Materi

e. Halaman Menu Kuis

Pada halaman Menu kuis ini ada tombol Kuis untuk melakukan evaluasi belajar dan Remedial Kuis untuk siswa yang mengulang kembali evaluasi jika nilai nya dibawah 80 . Tombol Home untuk kembali ke Menu uama. 


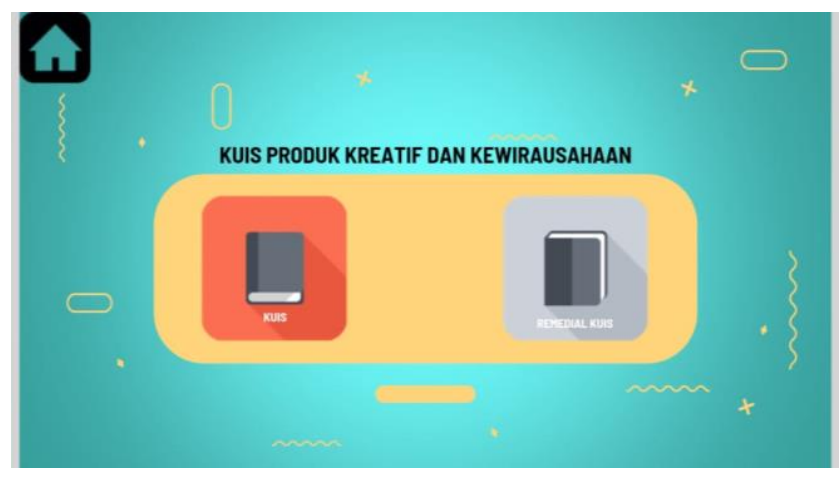

Gambar 11. Halaman Menu kuis

Ketika klik Menu Kuis, maka akan muncul gambar seperti dibawah ini :

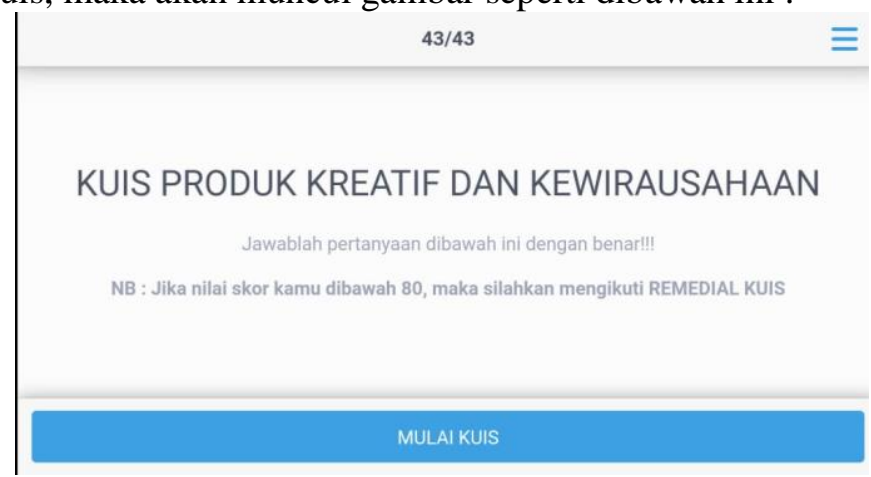

Gambar 12. Halaman kuis

Setelah siswa mengikuti kuis 25 soal Produk Kreatif dan Kewirausahaan akan keluar hasil nilai siswa dan nilai nya akan otomatis bisa langsung di lihat oleh guru melalui e-mail.

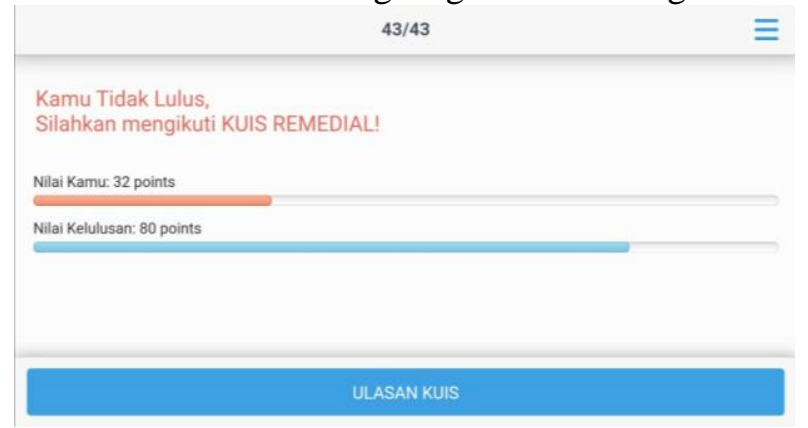

Gambar 13. Halaman Nilai

f. Halaman Kamus UKM

Halaman kamus UKM ini semacam buku rujukan berisikan istilah-istilah tentang bisnis atau Usaha Kecil Menengah untuk mengenal perkataan dalam wirausaha seperti pada gambar berikut :

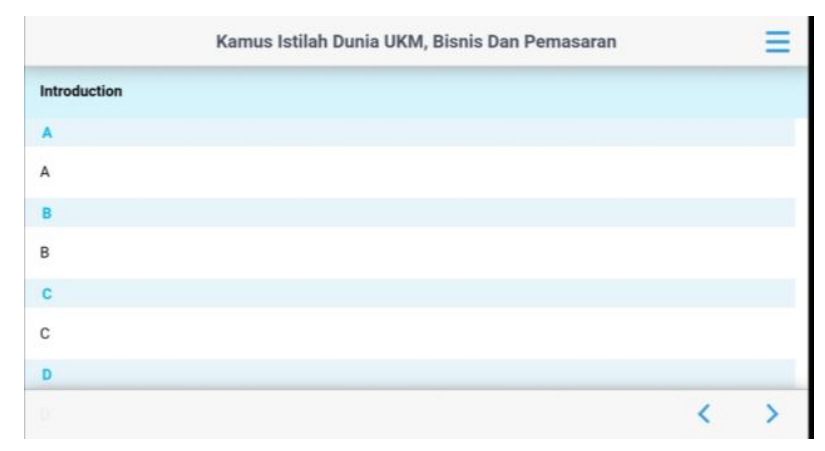


g. Halaman Menu Profil

Pada halaman Menu Profil ini berisi biodata penulis. Tombol Home untuk kembali ke Menu utama.

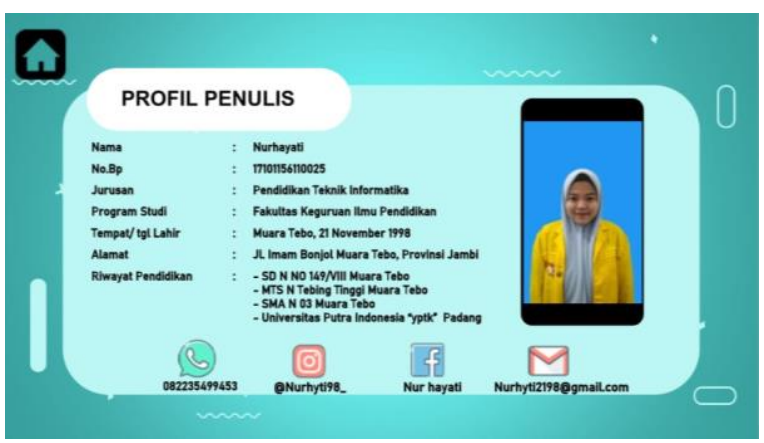

Gambar 15. Halaman Profil

h. Halaman Games

Halaman Games ini bentuk permainan puzzle yang dibuat untuk memperoleh pengetahuan tentang pengusaha yang sukses di dunia yang berkaitan dengan mata pelajaran Produk Kreatif dan Kewirausahaan agar siswa tidak jenuh dan bosan. Tombol Home untuk kembali ke Menu.

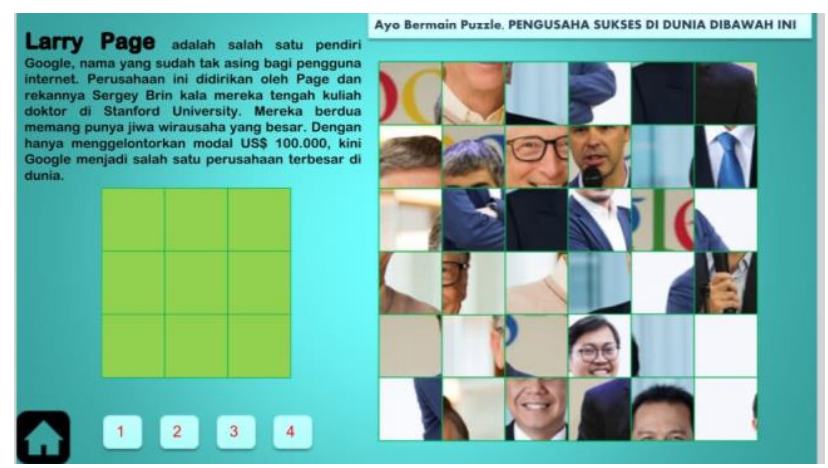

Gambar 16. Halaman Games Puzzle

i. Halaman Petunjuk

Halaman ini adalah petunjuk penggunaan media bagi siswa yang belum memahami dalam menjalankan aplikasi.

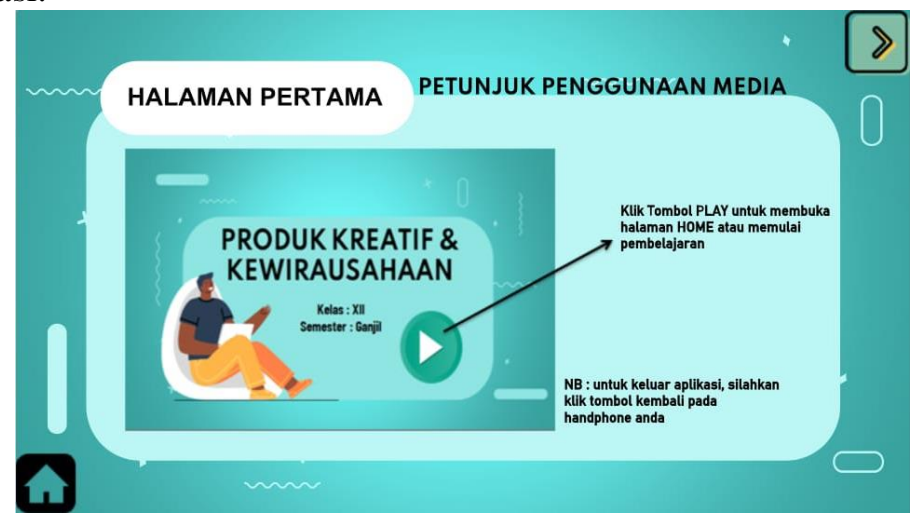

Gambar 17. Hamalan Petunjuk 
Berdasarkan hasil penelitian dari produk media pembelajaran berbasis Android mata pelajaran Produk Kreatif dan Kewirausahaan kelas XII TKJ 2 di SMK Negeri 8 Padang. Perancangan dan Pembuatan Aplikasi Media Pembelajaran Berbasis Android Pada Mata Pelajaran Produk Kreatif dan Kewirausahaan Kelas XII TKJ 2 di SMK N 8 Padang Semester Ganjil Tahun Ajaran 2020/2021 valid di gunakan karena sudah di lakukan uji penelitian tiga orang validator dengan hasil rata-rata pada pengujian validator yaitu $82,20 \%$. Hasil penelitian secara keseluruhan penilaian uji kepraktisan terhadap aplikasi Android dalam aplikasi media pembelajaran Produk Kreatif dan Kewirausahaan sebesar 90,79\% sehingga tingkat kepraktisan dapat di interpretasikan sangat praktis digunakan dan Hasil penelitian secara keseluruhan penilaian uji keefektifan terhadap aplikasi Android dalam media pembelajaran Produk Kreatif dan Kewirausahaan sebesar 84,91\% sehingga tingkat keefektivan dapat di interpretasikan efektif digunakan.

\section{KESIMPULAN}

Perancangan dan pembuatan media pembelajaran berbasis android mengikuti prosedur dan pengembangan (Research and Development) Sugiyono (2014:298). Berdasarkan diskripsi, analisis data, dan pengembangan Media pembelajaran berbasis android dapat disimpulkan sebagai berikut

a. Validitas melalui penilaian uji validator terhadap Aplikasi Media pembelajaran berbasis android sebesar 82,20\%, sehingga tingkat validitas dapat di interpretasikan Valid digunakan pada Mata Pelajaran Produk Kreatif dan Kewirausahaan Kelas XII TKJ 2 SMK N 8 Padang.

b. Praktikalitas Aplikasi media pembelajaran berbasis android adalah sebesar 90,79\%, sehingga tingkat praktikalitasnya dapat di interpretasikan Sangat Praktis digunakan pada Mata Pelajaran Produk Kreatif dan Kewirausahaan Kelas XII TKJ 2 SMK N 8 Padang.

c. Efektivitas Aplikasi media pembelajaran berbasis android adalah Sebesar 84,91\%, sehingga tingkat efektivitasnya dapat di interpretasikan Efektif digunakan pada Mata Pelajaran Produk Kreatif dan Kewirausahaan Kelas XII TKJ 2 SMK N 8 Padang.

\section{DAFTAR PUSTAKA}

[1] Arsyad, Azhar. 2016. Media Pembelajaran. Jakarta: Raja Grafindo Persada.

[2] Hamzah, dkk. 2014. Variabel Penelitian dalam Pendidikan dan Pembelajaran. Jakarta: PT. Ina Publikatama.

[3] Menrisal, Menrisal, Yuliawati Yunus, and Nurul Sari Rahmadini. "Perancangan dan Pembuatan Modul Pembelajaran Elektronik Berbasis Project Based Learning Mata Pelajaran Simulasi Digital SMKN 8 Padang." Jurnal Koulutus 2.1 (2019): 1-16.

[4] Prasetya, Wahyu Jati. 2015. Pengembangan Media Pembelajaran Flash Untuk Membaca Pemahaman Kelas XI Dengan Strategi $K$-W-L. S1 thesis, Universitas Negeri Yogyakarta.

[5] Purwanto. 2011. Evaluasi Hasil belajar. Yogyakarta: Pustaka Pelajar

[6] Rusman. 2012. Belajar dan Pembelajaran Berbasis Komputer. Bandung:Alfabeta.

[7] Sugiyono. 2014. Metode Penelitian Pendidikan (Pendekatan Kuantitatif, Kualitatif, dan $R \& D)$. Bandung: Alfabeta.

[8] Sugiyono. 2016. Metode Penelitian Pendidikan (Pendekatan Kuantitatif, Kualitatif, dan $R \& D$ ) . Bandung: Alfabeta.

[9] Yanti, dkk. 2014. Pengembangan Media Interaktif Berbasis Komputer Pada Materi Sistem Peredaran Darah Manusia Untuk SMA. Jurnal PELANGI.

[10] Nurlatifa.2015. Pengembangan Media Pembelajaran Ipa Berbasis Microsoft Office Powerpoint Interaktif Pada Siswa Kelas IV SD Negeri Ngrukeman Kasihan Bantul. Yogyakarta: Universitas PGRI. 